\title{
Results of long-term use of pheromone traps to monitor harmful tortricid moths in Leningrad Region of Russia
}

\author{
Elena Ovsyannikova, and Igor Grichanov* \\ All-Russian Institute of Plant Protection, Pushkin, St. Petersburg, 196608 Russia
}

\begin{abstract}
Monitoring the population dynamics of harmful moths using synthetic sex attractants in Leningrad Region was carried out in the fruit experimental orchard of St. Petersburg Agrarian University (Pushkin) and small private orchards of Pushkin district. As a result of the analysis of many years temperature characteristics of vegetation seasons in the Leningrad Region and calculation of the sums of effective temperatures, it has been found that the codling moth had high numbers and developed in two full generations in 1999, 2002, 2006, 2013 and 2018. The complex of phytophagous leaf rollers as a whole can cause sometimes significant harm to both industrial orchards and homestead lands, because the economic threshold of harmfulness by yield losses is often achieved, when plants are damaged by more than one pest species, each of which causing only weak harm. As a general conclusion, the complex of orchard leaf rollers is a dynamic system. Their development and numbers ratio is influenced by weather conditions of a year and climate changes in general.
\end{abstract}

\section{Introduction}

Pheromone monitoring is the most important element of the modern integrated system of fruit crop protection from the complex of moths in different natural and climatic conditions $[1,2]$. Our research was carried out in the Leningrad Region of the Russian Federation, where apple is a key fruit culture. A tangible loss in fruit yield here is due to the harmfullness of codling moth Cydia pomonella (L.) and a complex of harmful Tortricidae (Lepidoptera). Pheromones are known for all major species of this group, being widely used in traps as a method of their monitoring.

\section{Materials and methods}

\footnotetext{
*Corresponding author: grichanov@mail.ru
} 
Monitoring the population dynamics of harmful moths using synthetic sex attractants in Leningrad Region was carried out in the fruit experimental orchard of St. Petersburg Agrarian University (Pushkin) and small private orchards of Pushkin district in 1997-2004, 2006-2014 and 2018-2019. In different years, pheromone materials produced by the company "Flora" (Estonia) and "Shchelkovo Agrokhim" (Moscow, Russia) were used in delta traps made of laminated cardboard with an adhesive surface of $18 \times 10 \mathrm{~cm}$. Traps for the codling moth were placed in orchards at the end of flowering, at the western or southwestern sides of an apple tree at a height of about 1.5-2 m, one trap per 2 hectares, at a distance of 30-50 meters from each other [3]. Traps placed in the private orchards were checked daily, in the University experimental fruit orchard - 1-2 times a week. Adhesive papers were replaced as they were contaminated, usually in two to three weeks, and every week during the period of mass flight. Data from the nearest weather stations were used to analyze the temperature dynamics during vegetation seasons.

\section{Results and discussion}

The trend of climate warming in the northern European part of Russia is well known. Our main task was to study the development of the northern population of main pest of pome crops, the codling moth, in modern conditions of climate change in north-west Russia (on the example of Leningrad region). Regarding the northern edge of the pest area, the old Russian literature contains an expert assessment that only half of the caterpillars of the first generation can finish feeding before the cold [4]. Our observations in Pushkin have revealed appearance of caterpillars and even moths of a new (second) summer generation in August during the warm years between 1997 and 2019. Their offspring may completely or partially die, but this fact itself suggests that the share of first-generation caterpillars finishing development has increased significantly, and the increased wintering reserve of the pest can cause more serious harm next season. So, climate warming can lead to fuller development of the first generation, an increase in the share of healthy moths and their fertility next season, and an unpredictable increase of harmfulness.

As a result of the analysis of many years temperature characteristics of vegetation seasons in the Leningrad Region and calculation of the sums of effective temperatures (SET), we have found that the codling moth had high numbers and developed in two full generations in 1999, 2002, 2006, 2013 and 2018 [5-8] (Fig. 1).

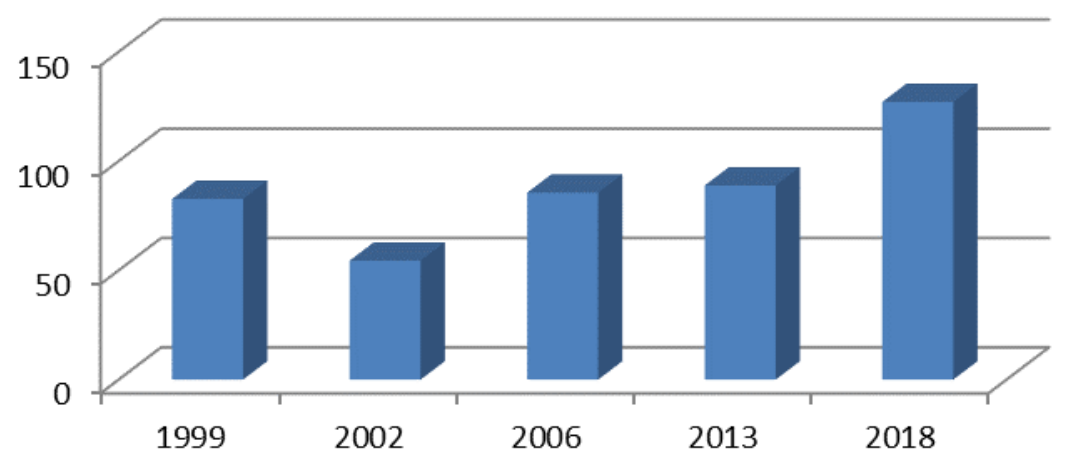

Fig. 1. Trapping Cydia pomonella during years with two full generations in Leningrad Region.

The vegetation seasons of five years with the full development of the second generation of the codling moth were characterized by high temperature compared to the many year average data against the background of precipitation deficit (Table 1). 
Table 1. Analysis of meteorological data of vegetation seasons with two full generations of Cydia pomonella in Pushkin.

\begin{tabular}{|c|c|c|c|c|c|c|c|c|c|c|c|c|}
\hline \multirow{3}{*}{ Month } & \multicolumn{6}{|c|}{ Temperature, ${ }^{\circ} \mathrm{C}$} & \multicolumn{6}{|c|}{ Precipitation } \\
\hline & \multirow[b]{2}{*}{ norm } & \multicolumn{5}{|c|}{ anomaly } & \multirow{2}{*}{$\begin{array}{c}\text { norm } \\
\mathrm{mm}\end{array}$} & \multicolumn{5}{|c|}{$\%$ of norm } \\
\hline & & ڤे & రి & \&્ర & $\stackrel{m}{\stackrel{n}{\sim}}$ & $\stackrel{\infty}{\stackrel{\infty}{\sigma}}$ & & ڤे & ঠి & ঃั & $\stackrel{m}{\stackrel{n}{\sim}}$ & $\stackrel{\infty}{\stackrel{d}{d}}$ \\
\hline May & 11.3 & -3.2 & +1.5 & +0.9 & +3.1 & +3.8 & 46 & 43 & 45 & 132 & 111 & 24 \\
\hline June & 15.7 & +4.9 & +1 & +1.2 & +4.1 & +0.5 & 71 & 45 & 105 & 80 & 52 & 32 \\
\hline July & 18.8 & +2.9 & +2.7 & +1.1 & +2.0 & +2.1 & 79 & 35 & 147 & 21 & 106 & 122 \\
\hline August & 16.9 & 0 & +2.4 & +2.5 & +1.7 & +2.3 & 83 & 64 & 48 & 57 & 117 & 75 \\
\hline September & 11.6 & +1.9 & +0.7 & +3.2 & +0.5 & +3.7 & 54 & 28 & 96 & 61 & 86 & 66 \\
\hline $\begin{array}{l}\text { May - } \\
\text { Sep- } \\
\text { tember }\end{array}$ & 14.9 & +0.7 & +1.2 & +1.4 & +1.9 & +2.6 & 333 & 44 & 91 & 64 & 97 & 70 \\
\hline
\end{tabular}

It should be also noted that the 2010 summer was similarly warm, but almost daily rains in May and June negatively affected the development of the first generation, thus reducing its number (totally 9.6 males were caught per trap during the season). The codling moth flight dynamics confirms the SET calculation data for the Leningrad region. The beginning of moth flight in years with two full generations was noted at the end of May at SET $88.4-$ $144.2^{\circ}$.

For example, 2018 observations on the flight dynamics and the codling moth number have shown that the SET $500^{\circ}$ required for the development of the first generation [9] was reached before July 20 , and SET $1000^{\circ}$ required for the development of the full second generation - by the end of the first third of September. Consequently, we can assume that a substantial part of the population had emerged from diapause by early July and produced a powerful surge in the moth flight of first generation, which has initiated the development of second generation of the codling moth. Pre-diapausing caterpillars have been found in the fruit drop during July-August. A weak moth flight of the second generation has been recorded in the last third of August, which nevertheless indicates the complete development of this generation and even the withdrawal of a small part of the caterpillars from the diapause. Eggs of the third generation have not been found. But even if the egg laying has happened, the all caterpillars hatched in September certainly have died due to a steady decrease of the average daily temperature below $10^{\circ} \mathrm{C}$ since September 25 and the first frosts since October 8.

Regarding harmful leaf rollers (Tortricidae), Bichina and Markelova [10] listed more than 50 species of this group in orchards on the territory of the former USSR in addition to the codling moth. Markelova [11] mentioned 14 tortricid species as pests of fruit and berry crops in Leningrad Region, of which Archips rosana (L.) and Exapate congelatella (Cl.) were the most harmful species of berries. Our long-term trials of 54 standard and experimental preparations of synthetic sex pheromones have revealed 41 species of Tortricidae trapped in orchards of the Pushkin district of Leningrad Region, of which 16 species have been found in apple orchards: Acleris bergmaniana (Linnaeus), Adoxophyes orana (Fischer von Röslerstamm), Aethes rubigana (Treitschke), Ancylis badiana (Denis \& Schiffermüller), Aphelia paleana (Hübner), Apotomis infida (Heinrich), Archips podana (Scopoli), A. rosana (Linnaeus), Choristoneura diversana (Hübner), Clepsis spectrana (Treitschke), Cnephasia stephensiana (Doubleday), Cochylis dubitana (Hübner), C. posterana Zeller, Cydia nigricana (Fabricius), C. pomonella (Linnaeus), C. servillana (Duponche), Dichrorampha petiverella (Linnaeus), Enarmonia formosana (Scopoli), Epiblema foenella (Linnaeus), E. scutulana (Denis \& Schiffermüller), Eucosma 
campoliliana (Denis \& Schiffermüller), E. cana (Haworth), Eulia ministrana (Linnaeus), Gypsonoma minutana (Hübner), G. sociana (Haworth), Grapholita funebrana (Treitschke), Hedya dimidiana (Clerck), H. nubiferana Haworth, Notocelia rosaecolana (Doubleday), Pammene rhediella (Clerck), Pandemis cerasana (Hübner), P. corylana (Fabricius), P. heparana (Denis \& Schiffermüller), Phalonidia manniana (Fischer von Röslerstamm), Ptycholoma lecheana (Linnaeus), Rhopobota naevana (Hübner), Spatalistis bifasciana (Hübner), Spilonota ocellana (Denis \& Schiffermüller), Syndemis musculana (Hübner), and Tortrix viridana Linnaeus.

This complex of phytophagous leaf rollers as a whole can cause sometimes significant harm to both industrial orchards and homestead lands, because the economic threshold of harmfulness by yield losses is often achieved, when plants are damaged by more than one pest species, each of which causing only weak harm. The most abundant in the Leningrad Region orchard pests during the last decade were Cydia pomonella, Hedya nubiferana, Archips podana, and Spilonota ocellana. Their numbers ratio in pheromone traps varied depending on the conditions of a vegetation season. As an example, we provide a comparison of C. pomonella and A. podana moths trapped in 2000-2019 (Fig. 2). In 2019, the warm May $(+0.8)$ and especially June $(+3.8$ above norm $)$ with the deficit of precipitation have caused a great increase in the number of Pandemis cerasana moths $(52.1$ males/trap per season), being a limiting factor for the development of Archips rosana and Spilonota ocellana.

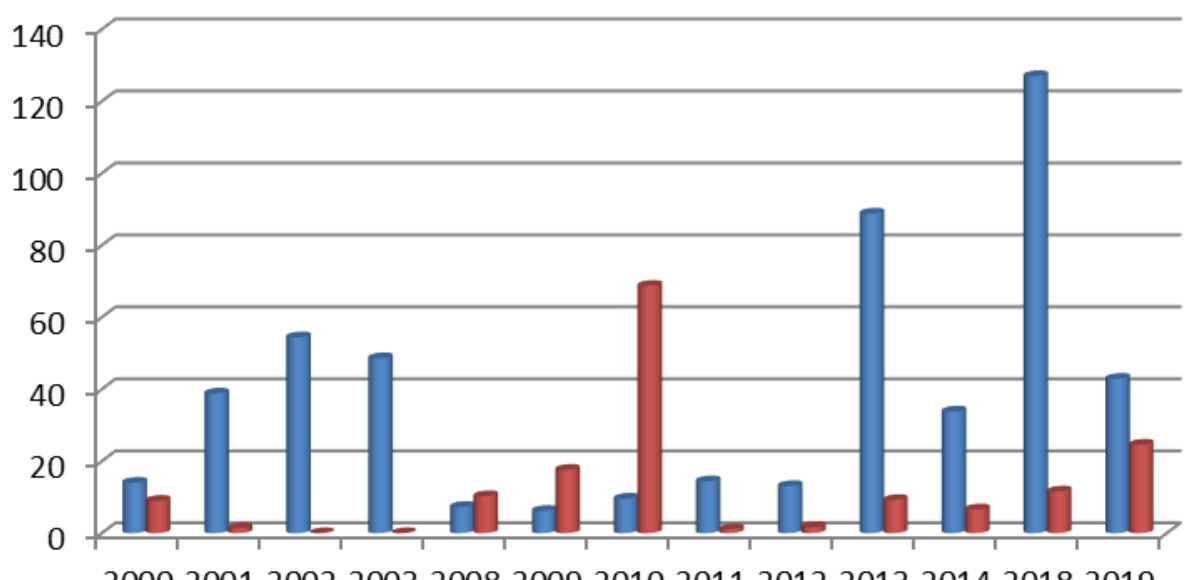

2000200120022003200820092010201120122013201420182019

Cydia pomonella $\quad$ Archips podana

Fig. 2. Trapping Cydia pomonella and Archips podana in 2000-2019 in Pushkin.

As a general conclusion, the complex of orchard leaf rollers is a dynamic system. Their development and numbers ratio is influenced by weather conditions of a year and climate changes in general. There is a trend to complicate the tortricid species composition due to the significance growth of potential apple pests. Such pests as Eulia ministrana, Rhopobota naevana, Choristoneura lafauryana (Ragonot), Pandemis dumetana (Treitschke), and Gypsonoma dealbana (Frölich) can join the codling moth as important pests of apple orchards. Pheromone monitoring allows controlling the composition and dynamics of the tortricid complex. It is a reliable way for use in both industrial orchards and homestead lands. 
We are grateful to Dr. S.Yu. Sinev (Zoological Institute, Russian Academy of Sciences, St. Petersburg) for his help on the tortricid species identification. The work was performed within the Program for Basic Scientific Researches in the Russian Federation for the Long-Term Period (20132020) approved by Order No. 2538-r of the Government of the Russian Federation dated December 27, 2012, and supported by the All-Russian Institute of Plant Protection project N 0665-2019-0014.

\section{References}

1. V.N. Burov, A.P. Sazonov, Biologically active substances in plant protection, 1-196 (Moscow, 1987)

2. Z.V. Nikolaeva, Agro XXI, 2, 12-13 (2001)

3. T.V. Ivanova, E.R. Myttus, Izv. AN ESSR, Biologiya, 34, 1, 29-33 (1985)

4. A.S. Danilevskiy, V.I. Kuznetsov, Fauna SSSR, Nasekomye Cheshuekrylye, 5, 1, Tortricidae Laspeyresiini, 1-635 (Leningrad, 1968)

5. I.Ya. Grichanov, E.I. Ovsyannikov, International Forum "Land and Yield" (III Conference "Market and Rational Use of Fertilizers and Agrochemical Products", June 5-8, 2007, St. Petersburg, Abstracts), 80-81 (St. Petersburg, 2007)

6. E.I. Ovsyannikov, I.Ya. Grichanov, Zashchita i Karantin Rasteniy, 5, 28-30 (2019)

7. E.I. Ovsyannikova, I.Ya. Grichanov, 3, 20-28 (2002)

8. E.I. Ovsyannikova, S.N. Smirnov, I.Ya. Grichanov, Plant Protection News [Vestnik Zashchity Rasteniy] 4, 72 (2013)

9. M.I. Boldyrev, Prediction of harmfulness of codling moth and short-term forecasting time of its control (methodological recommendations), 1-45 (Michurinsk, 1981)

10. V.P. Markelova, Transactions of Leningrad Agricultural Institute, 56-62 (Leningrad, 1960)

11. T.I. Bichina, E.M. Markelova, Orchard leaf rollers, 1-74 (Moscow, 1957) 